\title{
Effect of diet (fatty acid and protein) content during spawning season on fertility, eggs and larvae quality of common porgy (Pagrus pagrus, Linnaeus 1758)
}

\author{
Azeddine Abrehouch ${ }^{1 *}$; Ali Ait Ali $^{1}$; Kamal Chebbaki ${ }^{1}$; Houda Akharbach ${ }^{1}$; Mohamed \\ Idaomar $^{2}$ \\ ${ }^{1}$ Centre Spécialisé en Aquaculture. BP 31, INRH. M'diq. Morocco \\ ${ }^{2}$ Faculté des Sciences et Techniques, Tanger. Morocco. \\ * Corresponding author: Tel (212) 539663170 Fax: (212) 539975506 \\ E-mail:abraze1@yahoo.fr

\section{ABSTRACT}

\begin{abstract}
Spawning in captivity of two red porgy's broodstock groups (Pagrus pagrus) of the same age was studied during one season. These two broodstock groups, designed $A$ and $B$, were fed with different regimes during the spawning period. A group was fed on moist pellet while (A diet content $45 \%$ proteins, $10 \%$ lipids) B group was fed on fresh fish (A diet content $48 \%$ protein, $8.7 \%$ lipids). The total eggs collected number for $A$ group was 22 million eggs of which 18 million were viable, fertility was 474,966 eggs $\mathrm{kg}^{-1}$ female. For B group, eggs collected number was 36

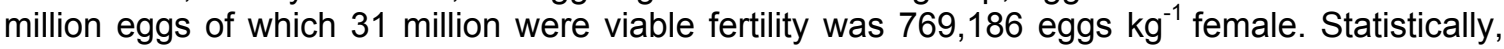
there was a significant difference between the two groups in terms of quantity and quality of spawning and larval survivals recorded on second day after hatching and on fifth day after hatching.
\end{abstract}

Keywords: Pagrus, red porgy, spawning, egg quality, fertility, broodstock. feeding

\section{INTRODUCTION}

Mediterranean fish farming production is characterized by the dominance of two species, the sea bass, Dicentrarchus labrax, and the sea bream, Sparus aurata The red porgy, Pagrus pagrus, a new candidate for aquaculture, seems to satisfy some of the criteria for the selection of a new species in intensive fish farming such as, high market price and demand, ability to fast growth but research on broodstock nutrition is still needed. Broodstock nutrition remains one of the most understood in the field of fish nutrition, and studies are limited to a few species (Brooks et al., 1997, Izquierdo et al., 2001). This is due to the need for large facilities, both inside and outside; to take a large number of adult fish and, consequently, the high cost needed to develop experience on feeding broodstock. In aquaculture, obtaining gametes quality can sometimes be problematic, especially when it becomes necessary to adjust production to market demand, control the timing of obtaining gametes, controlling environmental factors. As regards the production of fish eggs, these problems are more acute that the determinism inherent in the quality of fish oocyts is poorly known, including among species for which livestock is best controlled. The development of fish larvae appeared most affected by nutritional factors during the first days of life, even when they feed partly on their yolk reserves. Many authors have shown the influence of broodstock nutrition on the quality of larvae hatching. Notably, the viability of fry was related to their HUFA content itself linked to the HUFA content fed to broodstock (Lavens et al., 1999). Gonada development and fertility are affected by certain nutrients, particularly for parents with a continuous deck and a short period vitellogenesis. Thus, over the past two decades, more attention has been accorded to the level of different nutrients in broodstock nutrition. However, studies on broodstock nutrition are limited and relatively expensive to achieve. Lipid and fatty acid composition of broodstock nutrition has been identified as major dietary factors that determine reproductive success and survival. Some species of fish readily incorporate the dietary unsaturated fatty acids in eggs, even during the breeding season. In some fish species, LC-PUFA (Long chain polyunsaturated fatty acids) in broodstock nutrition increase fertility, fertilization and egg quality. This has been described in species such as sea bream, Sparus aurata (Mourente and Odriozola, 1990, Fernandez-Palacios et al., 1995, 1997), halibut, Hippoglossus hipoglossus (Bruce et al., 1993; Mazorra et al., 2003), sea bass, Dicentrarchus labrax (Cerdá et al., 1994b; Carrillo et 
al., 1995; Navas et al., 1997), Japanese sea bream, Pagrus major (Watanabe et al., 1984a,b,c,d; 1985 a,b; 1991), trout rainbow, Oncorhynchus mykis (Washburn et al., 1990; Choubert and White, 1993; Choubert et al., 1998) Atlantic salmon, Salmo salar (Eskelinen, 1989; Christiansen and Torrissen, 1997), coho salmon, Oncorhynchus kisutch (Hardy et al., 1984; 1990), tilapia, Oreochromis niloticus (Cumaratunga and Mallika, 1991; Gunasekera et al., 1995, 1996a, b, 1997; Siddiqui et al., 1998), common carp Cyprinus carpio (Manissery et al., 2001)Japanese flounder, Paralichthys olivaceus (Furuita et al., 2003, ) yellowtail Seriola quinqueradiata (Agius et al., 2001), Senegal sole, Solea senegalensis (Dinis et al., 1999), milkfish, Chanos chanos (Emata et al., 2000), turbot, Scophthalmus maximus (Lavens et al., 1999), and the catfish, Ictalurus punctatus (Torrans and Lowell, 2001).

The aim of this study is to determine how food quality of broodstock could affect fertility and egg quality.

\section{MATERIAL AND METHOD}

Brood stock: The red porgy broodstock was caught from wild individuals at M'diq Bay through small long liners. Caught porgies were kept in polyester rectangular tanks of volume $10 \mathrm{~m}^{3}$. These parents' fish were fed exclusively fresh fish (sardine) to satisfaction, once a day and six days a week. During the spawning period, they were divided into two groups (A and B). A group was composed of two males and fourteen females and $B$ group was constituted of two males and thirteen females.

Both groups were subjected to natural temperature, salinity and photoperiod conditions. The water renewal rate was kept around $300-500 \%$ per day and oxygenation was provided by three air arrivals. The average water temperatures during the reproductive period was $16.9 \pm 0.6^{\circ} \mathrm{C}$, varying between 15.9 and $19.2^{\circ} \mathrm{C}$. The spawning was spontaneous; it took place very early in the morning and fertilization occurred in water. The females and males average body weights of both groups $A$ and $B$ were respectively of $3.07 \pm 0.5 \mathrm{~kg}$ and $2.89 \pm 0.4 \mathrm{~kg}$. The total biomass of females was of $32.50 \pm 0.65 \mathrm{~kg}$ for $A$ group and $35.58 \pm 0.71 \mathrm{~kg}$ for $B$ group. A group received a diet based on moist diet composed of minced sardine $50 \%, 45 \%$ of dry pellet commercial and $3 \%$ fish meal flour, complex of vitamin and vitamin C. B group, was fed by fresh fish with $(50 \%)$, Squid $(35 \%)$ ) of shrimp (15\%) and complex of vitamin and vitamin C were added to the mixture(table1).

\section{Table1. Composition of the brood stock food}

\begin{tabular}{lllccccc}
\hline Ingredients & Sardine $^{1}$ & Bogue $^{2}$ & Shrimp $^{3}$ & Squid $^{4}$ & Pellet $^{5}$ & fish meal flour $^{6}$ & vitamin premix $^{7}$ \\
\hline A group & $50 \%$ & $0 \%$ & $0 \%$ & $0 \%$ & $45 \%$ & $3 \%$ & $2 \%$ \\
B group & $0 \%$ & $50 \%$ & $15 \%$ & $33 \%$ & $0 \%$ & $0 \%$ & $2 \%$ \\
\hline
\end{tabular}

${ }^{1}$ (Sardina pilchardus $),{ }^{2}$ (Boops boops ), ${ }^{3}$ (Solenocera membranacea), ${ }^{4}$ (Illex coindetii), ${ }^{5}$ (Pellet) $\quad{ }^{6}($ fish meal flour $),{ }^{7}$ Vitamin premix $\left(\right.$ dose $\mathrm{kg}^{-1}$ ): Minerals, 75\% ; Phosphorous, 3 - $4 \%$; Calcium 25 - 30\%, Vitamin A, 2.000000 IU ; Vitamin D3, 400000 IU ; Thiamine , 500 mg ; Riboflavin , 1.000 mg; pantothenatee Calcium , 7500 mg; Pyridoxine , 500 mg; Vitamin B $12,1,5$ mg; Tocophérol Acetate E, 2500 mg; Nicotinic Acid PP, 10000 mg; Choline (Chloride), $50000 \mathrm{mg}$

Table 2.Cumulative spawning of the two broodstock groups of common porgy during spawning season

\begin{tabular}{|c|c|c|c|c|c|}
\hline \multirow{2}{*}{$\begin{array}{l}\text { Year } \\
\text { Group } \\
\end{array}$} & \multicolumn{2}{|r|}{2007} & \multicolumn{3}{|c|}{2008} \\
\hline & A & $\mathrm{B}$ & A & & $\mathrm{B}$ \\
\hline Annual fecundity (1000 eggs $\mathrm{kg}^{-1}$ ) & $474.9 \pm 8.5^{\mathrm{a}}$ & $769.2 \pm 13.8^{b}$ & $192.1 \pm 3.8^{a}$ & $1021.4 \pm 20.4^{b}$ & \\
\hline Total eggs collected (x1000) & $22,344.7$ & $36,656.3$ & $5,022.8$ & $32,213.9$ & \\
\hline Viable eggs collected (x1000) & $18,850.3$ & $29,767.1$ & $2,887.1$ & $23,450.4$ & \\
\hline 2-day embryo survival & $53.82 \pm 0.97^{\mathrm{a}}$ & $70.00 \pm 1.26^{b}$ & $75.43 \pm 1.51^{a}$ & $78.97 \pm 1.58^{b}$ & \\
\hline Annual hatching rate & $40.05 \pm 0.72^{a}$ & $49.65 \pm 0.89^{b}$ & $48.06 \pm 0.96^{a}$ & $67.58 \pm 1.35^{b}$ & \\
\hline
\end{tabular}

There was a statistically significant difference between the two groups for the analyzed parameters $(A N O V A, P<0.05)$. $(n=2)$ 
Evaluation of eggs and larvae Quality: During 2007 season, spawning took place at temperatures ranged between 15.9 and $19.2^{\circ} \mathrm{C}$, with an average value of $16.9 \pm 0.6^{\circ} \mathrm{C}$. The eggs were harvested in eggs collector equipped with a mesh screen net of 500 micrometers. After harvesting, eggs were placed in a small tank of volume 30 liters; viable and dead eggs were separated and counted. Eggs and oil globule diameters were measured on a profile projector using digital calliper, through samples taken from each daily collected spawning during spawning season. Embryo development and larvae survival were followed using samples of collected eggs which were previously rinsed and stocked in $500 \mathrm{ml}$ beakers. These eggs incubated at ambient temperature and maintained until the death of all hatched larvae. Embryonic development was evaluated once a day, through profile projector and microscope observations. The number of hatched eggs and, the number of hatched viable larvae were evaluated daily. Various parameters of eggs quality were evaluated as, fertilized eggs rate which was evaluated daily as soon as the eggs were recuperated from the collector; it was calculated as the eggs number fertilized / total collected. Hatching rate was calculated as the number of hatched larvae / total incubated eggs. Larval survival was estimated as the numbers of live larvae on the second day after hatching (d) / the total hatched larvae number. Biochemical analysis of eggs composition concerned particularly: lipids and fatty acids. Humidity and ash were determined using standard method (AOAC, 2000).

Quantification of total lipids: Folch method: The determination of total lipids was done by the Folch method (Folch et al., 1957) by replacing chloroform by dichloromethane. The sample was ground with an Ultraturrax IKAT 25 in a mixture dichloromethane/methanol (2/1), containing $0.01 \%$ BHT (antioxidant agent) was then filtered vacuum 3 times (filter Wathman GF/A55mm deposited on membrane filter made of stainless steel, coated with silica).

Lipid methylation: The fatty acid composition was determined on the total lipids extracted by Folch method. The principle involves the methylation of lipids using boron trifluoride as catalyst. The extraction was done with n-hexane; esters obtained undergo evaporation of the solvent.

Analysis of Fatty Acid: Methylated FA was analyzed with a Varian 3400 GPC equipped with an automatic sampler. The column is a DB Wax capillary column
$(30 \mathrm{~m} \times 0.25 \mathrm{~mm}$ id, film thickness: $0.25 \mu \mathrm{m})$ from JW, USA. The temperatures of the injector split/splitless and flame ionization detector were 260 and $250{ }^{\circ} \mathrm{C}$, respectively. We worked with a split of 1:60. The carrier gas was helium with a flow rate of approximately $1 \mathrm{ml} / \mathrm{mn}$. Using a temperature gradient ranging from $100^{\circ}$ to $180^{\circ} \mathrm{C}$ to $8^{\circ} / \mathrm{min}$ then from 180 to $220^{\circ}$ to $4^{\circ} / \mathrm{min}$, stays at $220^{\circ}$ for 25 minutes (total time 45 minutes of analysis, allows to separate FA medium chain $\mathrm{C} 6$ to $\mathrm{C} 12$ ). FA are identified by comparison with mixtures of SIGMA or Supelco standards and quantified by computer system (Varian). SIGMA stds used:

FAS: $13=015=017=019=020=0$. Ref $189-6$ (Std sat)

Melange oil reference standard, AOCS, Ref O 7756 (Std 3)

FA D 22:4 w6 Ref 3534, Ref AG 22:3 w3 D 3909, Mixture AG Ref 189-19 (Std 4)

Stds Supelco used: FAME Mixture 37, Ref: 47885-U

Protein: The protein content (AOAC, 1995) was calculated from the composition in total nitrogen of the samples determined using Kjeldhal method.

Statistical analysis: Spawning and eggs quality comparison results between the two groups were treated using the ANOVA test (analysis of variance) to a minimum of significance $P<0.05$. The existence of a correlation between eggs quality parameters was examined on the basis of simple regression. The results are expressed as means \pm SEM. Statistical analysis was done with the software Stat graphic 5, Plus

\section{RESULTS}

The eggs were obtained from 13 February and were extended until 25 May. Cycles and thermophotoperiod, show that in spawning season, the porgy occurs in temperature and photoperiod bottom: 15.8 to $17.8^{\circ} \mathrm{C}$ and $12 \mathrm{~h} 14 \mathrm{~min}$ for the photoperiod (duration of daily illumination). The total number of eggs collected from two groups of parents ( $A$ and $B$ ), was estimated at $223,447,00,18,850,300$ with floating viable eggs (85\%) for A group with $31,524,418$ and $36,656,300$ viable eggs $(86 \%)$ for $B$ group. The total collected eggs from the two parents groups (A and $B$ ), during the spawning season are shown in Figure 1. In this figure, three peaks of spawning appeared for the two groups: the first from 13 to 27 February for A group and from 13 February to 4 March for the $B$ group, the second between 6 March and 8 May for B and between 6 March and 24 April for $A$ and the last between 10 and 22 May for 
two groups. The Peaks of $B$ group was larger and more prolonged than those of $A$ group.

Increased levels of n-3 HUFA food have reached a high level of lipids in eggs (Table 3 ). The most abundant fatty acids of total lipids in eggs were 16:0 (palmitic acid), 18:1 n-9 (oleic acid) and 22:6 n-3 (DHA) followed by 16:1 $n-7$ (palmitoleic acid), 18:0 (stearic acid) and 20:5 n-3 (EPA), regardless of the diet used. The n-3 fatty acids and n-3 HUFA increased significantly with increasing levels of dietary food, mainly due to increased 18:3 n-3 (linolenic acid), 18:4 n-3 (estearidonic acid) and EPA in eggs. Thus, a positive correlation was found between levels of $n-3$ HUFA in the diet and eggs content in n-3 HUFA. However, there were no significant differences between treatments on the eggs content of the groups of mono-saturated fatty acids, $n-6$ and $n-9$, although the levels of certain fatty acids such as food 18:0 (stearic acid), 18:1 n-9 (oleic acid) and 20:4 n-6 (AA) differed significantly between the two diets. The eggs biochemical composition did not show a significant difference between the two groups of eggs.

The fatty acid composition of eggs collected from the two broodstock groups during the spawning season are shown in Figure 2, n-3 PUFA in eggs stable throughout the spawning period for broodstock of $B$ group, against that eggs of $A$ group broodstock showed a considerable decrease in April without affecting the total PUFA content, as well the total number of collected eggs in this group has declined considerably in April which showed a direct relationship between the egg content of n-3 PUFA and the number of spawning eggs.

\section{DISCUSSION}

The total eggs production has made a big difference between the two groups. This difference was reflected also on the parameters of egg quality such as the larval hatching rate, 2-d larval survival and 5-d larval survival. As against, for the eggs size and oil globule levels during the spawning season, has not undergone significant changes, it was between 1.07 and $0.99 \mathrm{~mm}$, and between 0.24 and $0.22 \mathrm{~mm}$, respectively. Of all the spawning period, the average diameter of eggs was of $1020 \pm 20 \mu \mathrm{m}$ and the average oil globule diameter were $228 \pm 11 \mu \mathrm{m}$. The results for different marine fish and freshwater species, showed no relationship between the eggs biochemical composition, and eggs and larvae survival (Craik and Harvey, 1984; Kjørsvik et al., 1990). For the majority of research on eggs the quality, the fertilization rate and hatching were used as important criteria (Kjørsvik et al., 2003). Survival up to a certain development stage, and larvae production were also used as measures of quality (Fernandez-Palacios et al., 1995).

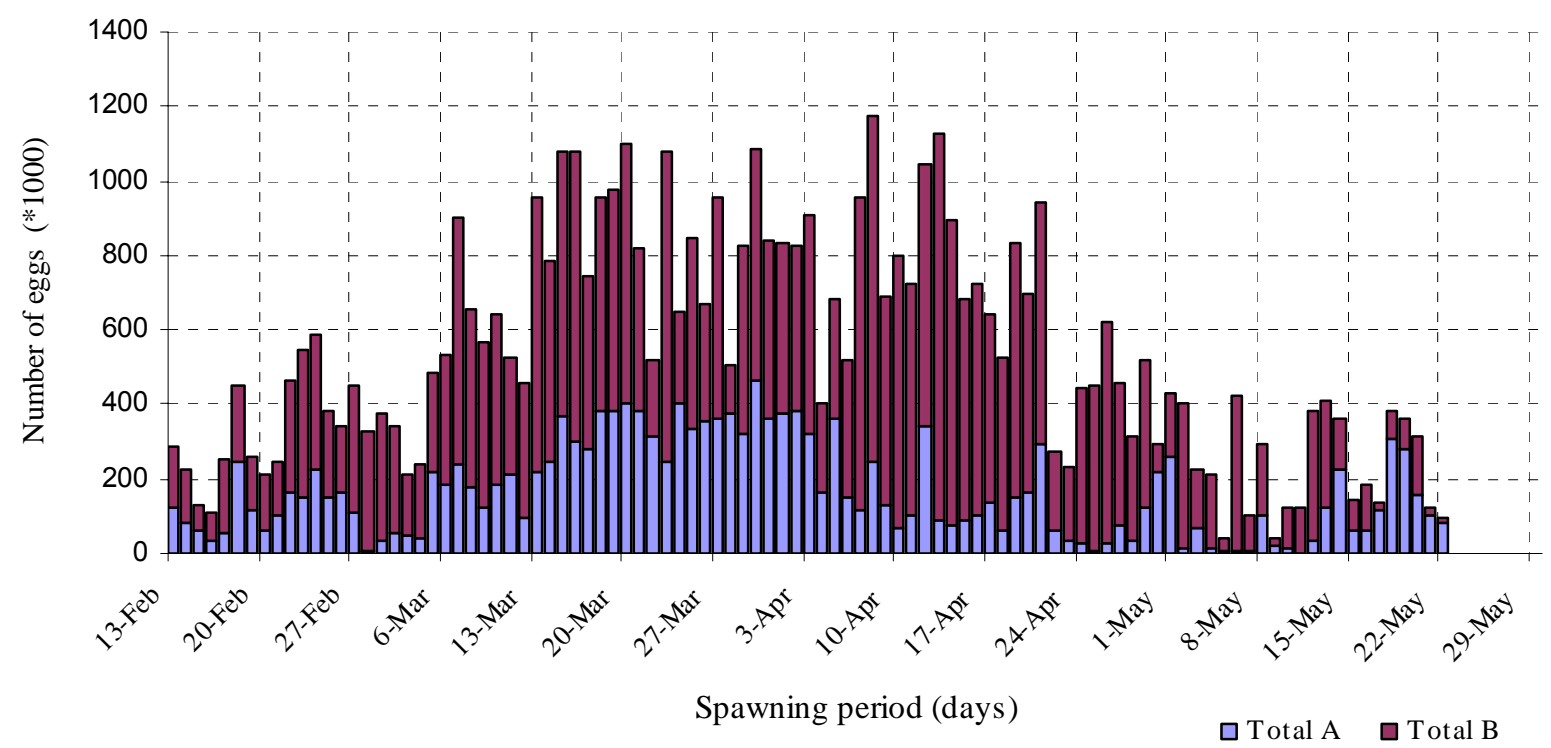

Fig. 1. Spawning frequency and number of eggs produced by $P$. pagrus brodstoock (A and B) during a spawning season. 
Agric. Biol. J. N. Am., 2010, 1(3): 175-184

Table 3. Fatty acid composition ( $\mathrm{mg} \mathrm{g}^{-1}$ lipid) of eggs from two broodstock groups common porgy ( $A$ and $B$ ) collected during the spawning season and the two foods ( $A$ and $B$ ) fed to the two broodstock groups.

\begin{tabular}{|c|c|c|c|c|c|c|c|c|c|c|}
\hline $\begin{array}{c}\text { \%TFA } \\
\text { total lipids }\end{array}$ & $A_{2}$ & $A_{3}$ & $A_{4}$ & $A_{5}$ & $\mathrm{~B}_{2}$ & $\mathrm{~B}_{3}$ & $B_{4}$ & $B_{5}$ & Diet A & Diet B \\
\hline $\begin{array}{l}\left(\mathrm{mg} \mathrm{g}^{-1} \mathrm{DW}\right) \\
\text { total FA }\end{array}$ & 72,90 & 53,90 & 64,90 & 72,20 & 78,30 & 52,50 & 62,10 & 67,70 & 106,20 & 87,20 \\
\hline$\left(\mathrm{mg} \mathrm{g}^{-1}\right.$ & & & & 914,05 & & & & & & \\
\hline lipid) & 698,29 & 771,36 & 848,88 & & 679,97 & 641,93 & 670,47 & 707,86 & 681,56 & 781,56 \\
\hline $14: 0$ & 2,17 & 2,49 & 3,00 & 2,21 & 2,36 & 2,52 & 2,52 & 2,87 & 5,90 & 2,80 \\
\hline $15: 0$ & 0,48 & 0,58 & 0,66 & 0,62 & 0,61 & 0,72 & 0,65 & 0,69 & 0,66 & 0,96 \\
\hline $16: 0$ & 20,98 & 18,00 & 24,81 & 20,07 & 20,87 & 20,85 & 20,37 & 20,19 & 20,48 & 18,48 \\
\hline $18: 0$ & 4,27 & 3,61 & 4,98 & 4,72 & 4,53 & 4,47 & 4,39 & 4,05 & 4,19 & 2,59 \\
\hline SFA & 27,89 & 24,68 & 33,45 & 27,62 & 28,37 & 28,56 & 27,93 & 27,80 & 31,23 & 33,83 \\
\hline $16: 1 n-9$ & 0,00 & 0,00 & 1,68 & 0,89 & 0,00 & 0,00 & 0,00 & 0,00 & 0,00 & 0,00 \\
\hline $16: 1 n-7$ & 7,60 & 7,41 & 10,29 & 6,93 & 6,99 & 8,85 & 7,14 & 6,51 & 6,87 & 10,87 \\
\hline $18: 1 n-9$ & 17,85 & 18,80 & 29,21 & 19,87 & 17,68 & 19,41 & 18,85 & 16,57 & 22,26 & 25,26 \\
\hline $18: 1 n-7$ & 2,46 & 2,35 & 0,00 & 0,00 & 2,65 & 2,62 & 2,41 & 1,77 & 2,28 & 2,78 \\
\hline $20: 1 n-9$ & 1,26 & 1,14 & 1,77 & 1,55 & 1,03 & 1,18 & 1,02 & 1,02 & 0,12 & 2,12 \\
\hline MUFA & 29,17 & 29,70 & 42,95 & 29,24 & 28,35 & 32,07 & 29,42 & 25,87 & 31,53 & 41,03 \\
\hline $18: 2 n-6$ & 2,63 & 4,89 & 4,99 & 4,40 & 3,48 & 2,05 & 2,01 & 2,95 & 9,89 & 12,89 \\
\hline $18: 3 n-6$ & 1,61 & 0,51 & 0,64 & 0,57 & 0,41 & 0,62 & 0,41 & 0,37 & 0,58 & 0,58 \\
\hline $20: 2 n-6$ & 0,00 & 0,00 & 0,00 & 0,00 & 0,00 & 0,00 & 0,00 & 0,00 & 0,00 & 0,00 \\
\hline $20: 3 n-6$ & 0,00 & 0,00 & 0,00 & 0,00 & 0,00 & 0,00 & 0,00 & 0,00 & 0,00 & 0,00 \\
\hline $20: 4 n-6$ & 1,45 & 1,14 & 1,10 & 0,97 & 1,20 & 1,28 & 1,42 & 1,69 & 0,62 & 1,62 \\
\hline $22: 4 n-6$ & 0,00 & 0,00 & 0,00 & 0,00 & 0,00 & 0,00 & 0,00 & 0,00 & 0,00 & 0,00 \\
\hline $22: 5 n-6$ & 0,00 & 0,00 & 0,00 & 0,00 & 0,00 & 0,00 & 0,00 & 0,00 & 0,00 & 0,00 \\
\hline n-6 PUFA & 5,69 & 6,54 & 6,73 & 5,94 & 5,09 & 3,96 & 3,84 & 5,01 & 11,09 & 15,09 \\
\hline $18: 3 n-3$ & 0,70 & 1,25 & 0,86 & 0,85 & 0,84 & 0,71 & 0,65 & 1,07 & 2,46 & 3,46 \\
\hline $18: 4 n-3$ & 1,56 & 1,43 & 1,09 & 1,77 & 1,48 & 1,24 & 1,19 & 1,49 & 2,78 & 3,68 \\
\hline $20: 3 n-3$ & 0,00 & 0,00 & 0,00 & 0,00 & 0,00 & 0,00 & 0,00 & 0,00 & 0,00 & 0,00 \\
\hline $20: 4 n-3$ & 0,64 & 0,74 & 0,38 & 0,62 & 0,74 & 0,69 & 0,80 & 1,08 & 0,50 & 0,50 \\
\hline $20: 5 n-3$ & 5,20 & 6,05 & 2,20 & 5,95 & 5,63 & 5,27 & 5,34 & 7,56 & 8,40 & 9,40 \\
\hline $21: 5 n-3$ & 0,19 & 0,25 & 0,07 & 0,22 & 0,24 & 0,12 & 0,22 & 0,29 & 0,30 & 0,90 \\
\hline $22: 5 n-3$ & 1,93 & 2,26 & 0,89 & 1,95 & 2,23 & 2,28 & 2,55 & 2,52 & 1,06 & 2,96 \\
\hline $22: 6 n-3$ & 26,32 & 26,62 & 10,68 & 25,22 & 26,57 & 24,77 & 27,62 & 26,88 & 9,03 & 27,03 \\
\hline n-3 PUFA & 36,53 & 38,61 & 16,17 & 36,58 & 37,73 & 35,08 & 38,37 & 40,88 & 24,53 & 47,93 \\
\hline Total PUFA & 42,22 & 45,15 & 22,90 & 42,52 & 42,82 & 39,04 & 42,21 & 45,90 & 35,63 & 63,03 \\
\hline $16: 4$ & 0,03 & 0,09 & 0,00 & 0,11 & 0,09 & 0,05 & 0,03 & 0,10 & 0,60 & 0,60 \\
\hline $16: 3 n-4$ & 0,46 & 0,23 & 0,39 & 0,22 & 0,15 & 0,09 & 0,20 & 0,23 & 0,75 & 0,95 \\
\hline $16: 2 n-4$ & 0,22 & 0,14 & 0,30 & 0,29 & 0,21 & 0,20 & 0,21 & 0,10 & 0,26 & 0,46 \\
\hline Total Others & 0,72 & 0,46 & 0,70 & 0,62 & 0,45 & 0,33 & 0,44 & 0,43 & 1,61 & 2,01 \\
\hline n-3 HUFA & 33.64 & 35.18 & 13.84 & 33.34 & 34.67 & 32.44 & 35.73 & 37.25 & 18.79 & 40.29 \\
\hline DHA/EPA & 5,07 & 4,40 & 4,84 & 4,24 & 4,72 & 4,70 & 5,17 & 3,56 & 1,08 & 2,88 \\
\hline$n-3 / n-6$ & 6,42 & 5,90 & 2,40 & 6,15 & 7,41 & 8,86 & 10,00 & 8,15 & 2,21 & 3,18 \\
\hline
\end{tabular}

DHA: docosahexaénoic acid; EPA: eicosapentaenoic acid; PUFA: polyunsatureted fatty acid 


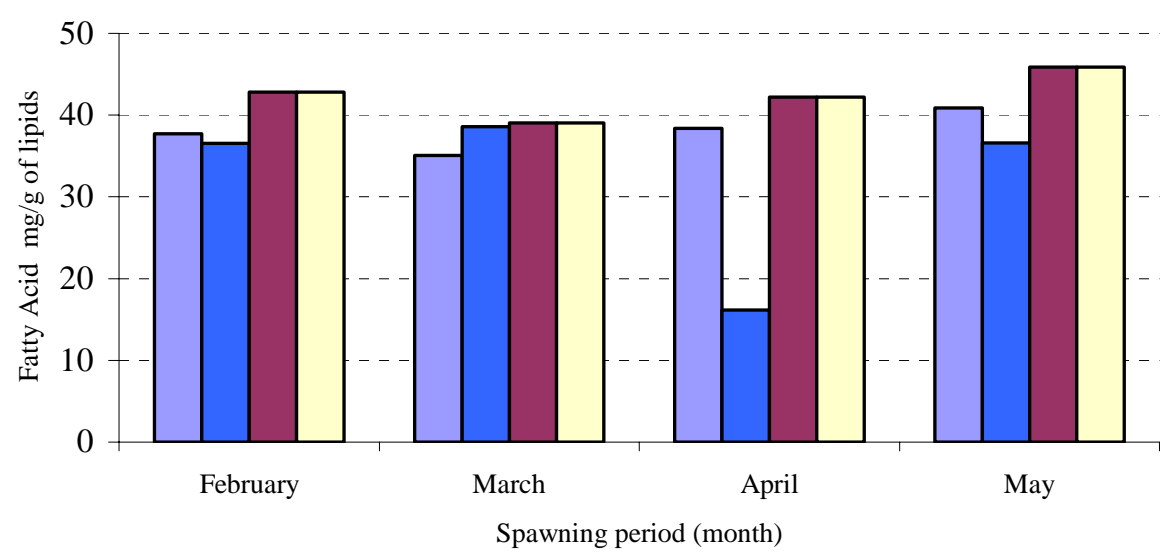

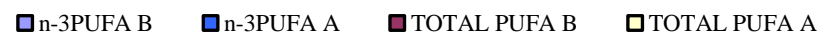

Fig. 2. Fatty acids Analysis of eggs collected from the two broodstock groups ( $A$ and $B$ ) during the spawning period

Recently proposed, the use of new spawning quality indicators such as genetic markers (Kestemont et al., 1999; Carnevali et al., 2000, 2001), the ash weight of the eggs (Trippel et al., 2000). Since the various parameters and eggs characteristics that have been proposed as indicators of the spawning quality for fish seem to be able to define the spawning quality a combination of different criteria provide a better result. Some studies carried out in the wild have shown that food availability is the primary determinant of fertility, which can be defined as the number of mature eggs produced per female during the annual cycle of egg spawning (Wotton, 1979; Bromage et al., 1992.). Some studies have been conducted on aquatic species that inhabit freshwater rivers with different food availability, showed that fish living in rivers of low productivity, provides low fertility. This has been reported for rutile, Rutilus rutilus (McKay and Mann, 1969; Kuznetzov and Khalitov, 1978), Gasterosteus acuelatus (Ali and Wooton, 2000). With reference to marine species, Bagenal (1966) reported that variations in fertility observed in natural populations of plaice, Pleuronectes platessa in Western Europe could be related to differences in food availability, its tour due to population density. Studies on the natural environment, show direct link between diet and fertility, similar studies were conducted on trout rainbow, Oncorhynchus mykiss, in captivity. These experiments have shown that reducing the required amount of food will cause a reduction in fertility and in some cases, the proportion of females reaching sexual maturity (Baïz, 1978). So, there is evidence that a long period of food restriction (8 months or more) has a negative effect on reproduction of the species (Scott, 1962) for marine fish; studies have also shown a negative effect of low food availability on fertility. Robb (1982) showed that egg production and food intake were positively correlated for haddock Melanogrammus aeglefinus maintained under laboratory conditions. As for other species, such as herring, Clupea harengus (Ma et al., 1998) the medaka Oryzias latipes (Hirshfield, 1980) or cod, Gadus morhua (Karlsen et al., 1995; Kjesbu et al., 1998). For some fish species like sea bream (Sparus aurata), or Japanese sea bream (Pagrus major) the composition of the egg is quickly affected by diet in a few weeks of feeding broodstock (Watanabe et al., 1985b, Fernandez-Palacios et al., 1995; Tandler et al., 1995). For these species, spawning was continuous with short periods of vitellogenesis; it is possible to improve the quality of spawning by altering the nutritional quality of broodstock diets during the same spawning period (FernándezPalacios et al., 1995, 1997, 1998; Tandler et al., 1995). Similarly, it is possible to improve the quality and hatchability of eggs during the spawning period in the sea bass (Dicentrarchus labrax) by feeding broodstock with appropriate quantities of HUFA during the vitellogenesis period which is slightly longer than that of seabream (Navas et al., 1997). Although the fatty acid profile of fish muscle and the development of eggs of coho salmon, Oncorhynchus kisutch (Hardy et al., 1990) correspond to fatty acids food profiles after only two months supply. The Turbot is an exception to this observation, it is 
important to feed parents on high nutritional quality regime during the vitellogenesis period and spawning. The results of this experiment indicate that the spawning quality of common porgy (Pagrus pagrus), which is a limiting factor for seed production of this species, is directly affected by the levels of $n-3$ HUFA in the diets of broodstock. These results are consistent with those found by Watanabe et al. (1984 a,b,c, 1985 a,b) for the Japanese sea bream (Pagrus major), Furuita et al. (2000, 2002) For the sole Pacific (Paralichthys olivaceus), Cerdá et al. (1994b), Navas et al. (1997) and Bruce et al. (1999) for the sea bass (Dicentrarchus labrax), Harel et al. (1994), Rodriguez et al. (1998), Almansa et al. (1999, 2001) and Domarco (2001) for sparus aurata. Given these characteristics, most of the essential fatty acids of eggs may be modified during the spawning season and thus affect the egg spawning quality (Almansa et al., 1999). According to this experiment, the egg quality composition of porgy was affected by the levels of essential fatty acids in experimental diets. Similarly, the viable eggs percentage increases with higher levels of n-3 HUFA in the diet and the incorporation of these fatty acids in eggs, which indicates the importance of these essential fatty acids for eggs and embryos normal development. Similar results for sea bream were described by Domarco (2001) in an experiment in which increasing levels of n-3 HUFA in eggs means an increase in the percentage of viable eggs. In contrast, larval survival was not correlated positively with levels of n-3 HUFA in food. An excess of n-3 HUFA in broodstock diet, produces a high percentage of larvae with an enlarged yolk sac and caused a $10 \%$ reduction of larval survival to 3 days after hatching. As suggested by several authors (Sandnes et al., 1984, Craik, 1986, Harel et al., 1994; Bell et al., 1997, Almansa et al., 1999), the eggs chemical composition was related to the quality of eggs and the composition of the egg must meet the nutritional needs of the embryo for its development and growth. But the results of this study showed that the percentage of n3 HUFA in eggs should not be used as the only criterion for determining the quality of eggs from broodstock porgy. In general, low levels of n-3 HUFA reduce the quality of eggs, but few authors Lavens et al. (1999) and Furuita et al. (2002) noted the negative effects caused by an excess of n-3 HUFA on egg. Lipids and fatty acid are dietary components that influence the quality of spawning, especially in those species that show up continually short vitellogenesis periods and are able to incorporate these dietary components in eggs even during spawning period.
Among broodstock, it would seem that a content of 27.5 to $35 \%$ protein is optimum for growth. Regarding the reproductive (spawning frequency, size of eggs, fertility and hatchability), the Wee and Tuan (1988) results suggest that diets low or medium protein $(20$, $27.5,35 \%$ ) favour high fertility, late spawning and frequent and small seize of eggs, whereas a diet rich in protein (42.5 and $50 \%$ ) allows for earlier spawning eggs, but less frequent. For sea bream, the estimates of need protein is $40 \%$ to $55 \%$, according to Yone, 1975 (Crysophrys major). for sea bass, the estimates are more uniform ranging from $50 \%$ (Alliot et al, 1974) to more $53 \%$ if one takes into account the work of Metailler et al, 1981, showing that the rate of growth is improved when the protein content is of 53 to $63 \%$. But even at higher rates, proteins are digested in the bar (Brigaudeau, 1981; Peres, 1981; Alliot, 1982) and remains an excellent source of energy

\section{CONCLUSION}

This work provides new information on spawning, egg production and quality characteristics of common porgy in captivity, and provides ample evidence on the effect of diet on the quality and quantity of eggs produced during the spawning season. This information is valuable for commercial hatcheries, particularly in regard to these broodstock requirements, spawning, egg production and egg quality and larvae survival. Further research on the reproduction of captive common porgy should focus on the effect of broodstock feeding, sex ratio and nutrition on egg production of quality.

\section{REFERENCES}

AOAC (Association of Official Analytical Chemists) S (2000). Official method of analysis, 17th edn. Association of Official Analytical Chemists MD, USA.

Agius RV, Watanabe T, Satoh S, Kiron V, Imaizumi $H$, Yamazaki T, Kawano K (2001). Supplementation of paprika as a carotenoid source in soft-dry pellets for broodstock yellowtail Seriola quinqueradiata (Temminck \& Schlegel). Aquaculture Research,32 (1): 263-272.

Ali M and Wootton RJ (2000). Variation in rates of food consumption and evidence for

compensatory responses in the three-spined stickleback, Gasterosteus aculeatus L. in relation togrowth and reproduction. Ecology of Freshwater Fish, 9 (1-2): 103108.

Alliot E (1982). Aspects nutritionnels chez le loup, Dicentrarchus labrax, en milieu contrôlé. Influences des régimes alimentaires et des facteurs de l'environnement sur le bilan azoté. Thèse de doctorat 
d'Etat. Uni versité d'Aix-Marseille II. Faculté des Sciences de Luminy.

Alliot E, Febvae A, Metailler R, Pastoureaud A (1974). Besoins nutritifs du bar (Dicentrarchus labrax). Etude du taux protéique en fonction du taux de lipide dans le régime. In Actes de Colloques № 1, colloque sur l'Aquaculture, Brest, Oct. 1973, 215-231.

Almansa E, Perez MJ, Cejas JR, Badia P, Villamandos JE, Lorenzo A (1999). Influence of broodstock gilthead seabream (Sparus aurata L.) dietary fatty acids on egg qualityand egg fatty acid composition throughout the spawning season Aquaculture, 170 (3-4): 323-336.

Almansa E, Martin MV, Cejas JR, Badia P, Jerez S, Lorenzo A (2001). Lipid and fatty acid composition of female gilthead seabream during their reproductive cycle: effects of a diet lacking n-3 HUFA. Journal of Fish Biology, 59 ( 2): 267-286.

Bagenal TM (1966). The ecological and geographical aspects of the fecundity of the plaice. J. Mar.Biol. Assoc. U.K., 46:161-186.

Baiz M (1978). Fecundity of reared rainbow trout, Salmo gairdneri. Ecologia, 3: 57-64.

Bell JG, Farndale BM, Bruce MP, Navas JM, M. CARILLO (1997). Effects of broodstock dietary lipid on fatty acid compositions of eggs from sea bass (Dicentrarchus labrax).Aquaculture, 149 (1-2): 107-119.

Brigaudeau BRP (1981). Les enzymes de la digestion intestinale du poisson Etude particulière chez le loup ou bar, Dicentrarchus labrax L. Thèse. Ecole Nationale vétérinaire de Toulouse, 1981, $71 \mathrm{pp}$.

Bruce MP, Shields RJ, Bell MV, Bromage NR (1993). Lipid class and fatty acid composition of eggs of Atlantic halibut, Hippoglossus hippoglossus (L.), in relation to egg quality in captive broodstock. Aquacult. Fish. Manage., 24 (3): 417-422.

Bromage NR, Bruce M, Basavaraja N, Rana K (1994). Egg quality determinants in finfish: the role of overripening with special reference to the timing of stripping in the Atlantic

Bromage N, Jones J, Randall C, Thrush M, Davies M, Springate J, Duston J, Baker G (1992). Broodstock management, fecundity, egg quality and timing of egg production in the rainbow trout (Onchorhynchus mykiss). Aquaculture, 100: 141-166.

Bruce M, Oyen F, Bell G, Asturiano JF, Farndale B, Ramos $\mathrm{J}$, bromage $\mathrm{n}$, Carrillo M, Zanuy $\mathrm{S}$ (1999). Development of broodstock diets for the European sea bass (Dicentrarchus labrax) with special emphasis on the importance of $n-3$ and n-6 HUFA to reproductive performance. Aquaculture, 117 (1-4): 85-97.

Carnevali O, Meiri I, Polzonetti V, Cambi A, RIdolfi S (2000). Sparus aurata eggs:Maturation and quality. In Norberg, B.; Kjesbu, O.S.; Taranger, G.L.; Andersson, E.; Stefansson,S.O. (Ed.). Proceedings of the 6th International Symposium on the Reproductive Physiology of Fish, p. 312.
Carnevali O, Mosconi G, Cambi a, Ridolfi S, Zanuy S, Polzonetti-magni AM (2001). Changes of lysosomal enzyme activities in sea bass (Dicentrarchus labrax) eggs and developing embryos. Aquaculture, 202 (3-4): 249-256.

Carrillo M, zanuy S, prat F, Cerda J, Mañanos E, Bromage N, Ramos J, Kah O (1995). Nutritional and photoperiodic effects on hormonal cycles and quality of spawning in sea bass (Dicentrarchus labrax L.). Netherlands Journal of Zoology, 45 (1-2): 204-209.

Cerdá J, Carrillo M, Zanuy S, Ramos J, De la Higuera M (1994b). Influence of nutritional composition of diet on sea bass Dicentrarchus labrax L., reproductive performance and egg and larvae quality. Aquaculture, 128: 345-361.

Choubert G, Blanc JM (1993). Muscle pigmentation changes during and after spawning in male and female rainbow trout, Oncorhynchus mykiss, red dietary carotenoids. Aquat. Living Resour.,6: 163-168.

Christiansen R, Torrissen OJ (1997). Effects of dietary astaxanthin supplementation on fertilization and egg survival in Atlantic salmon (Salmo salar L.). Aquaculture, 153 (1-2): 51-62.

Craik JCA, Harvey SM (1984). Egg quality in rainbow trout. The relation between egg viability,selected aspects of egg composition, and time of stripping. Aquaculture, 40: 115-134.

Craik JCA, Harvey SM (1986). Egg quality in the Atlantic salmon. Ices Council Meeting 1986(Collected Papers), Ices, Copenhagen (Denmark), 10 pp.

Cumaranatunga PR, Mallika KL (1991). Effects of different levels of dietary protein and a legume vigna catiang on gonadal development in Oreochromis niloticus (L.). Proceedings of The Fourth Asian Fish Nutrition Workshop. Special publication. Asian Fisheries Society.,5:125-133.

Dinis MT, Ribeiro L, Soares F, Sarasquete C (1999). A review on the cultivation potential of Solea senegalensis in Spain and in Portugal. Aquaculture, 176 (1-2): 27-38

Emata A, Borlongan I, Darnaso J (2000). Dietary vitamin C and $E$ supplementation and reproduction of milkfish Chanos chanos Forsskal. Aquaculture Research, 31(7): 557-564.

Eskelinen P (1989). Effects of different diets on egg production and egg quality of Atlantic salmon(Salmo salar L.). Aquaculture, 79 ( 1-4): 275-281.

Fernández-palacios $\mathrm{H}$, S. Izquierdo $M$, Robaina L, Valencia A, Salhi M, Vergara JM (1995). Effect of n-3 HUFA level in broodstock diets on egg quality of gilthead sea bream (Sparus aurata L.) Aquaculture, 132 (3-4): 325337.

Fernández-Palacios $\mathrm{H}$, Izquierdo MS, Robaina L, Valencia A, Salhi M, Montero D (1997). The effect of dietary protein and lipid from squid and fish meals on 
eggquality of broodstock for gilthead seabream (Sparus aurata). Aquaculture, 148 (2-3): 233-246.

Fernández-Palacios $H$, Izquierdo MS, Gonzalez $M$, Robaina L, Valencia A (1998). Combined effect of dietary a-tocopherol and n -3 HUFA on egg quality of gilthead seabrearn broodstock (Sparus aurata). Aquaculture, 161: 475-476.

Folch J, Lees M, Sloanne-Stanley GH (1957). A simple method for the isolation and purification of total lipids from animal tissues, J.Biol.Chem. 226(2): 497-509.

Furuita $\mathrm{H}$, Tanaka $\mathrm{H}$, Yamamoto $\mathrm{T}$, Shiraishi M, Takeuchi T (2000). Effects of n-3 HUFA levels in broodstock diet on the reproductive performance and egg and larval quality oft he Japanese flounder, Paralichthys olivaceus. Aquaculture, 187 (3-4): 387-398.

Furuita $\mathrm{H}$, Tanaka $\mathrm{H}$, Yamamoto $\mathrm{T}$, Suzuki N, Takeuchi $\mathrm{T}$ (2002). Effects of high levels of n-3 HUFA in broodstock diet on egg quality and egg fatty acid composition of Japanese flounder, Paralichthys olivaceus. Aquaculture, 210 (1-4): 323-333.

Furuita H, Yamamoto T, Shima T, Suzuki N, Takeuchi T (2003b). Effect of arachidonic acid levels in broodstock diet on larval and egg quality of japanese flounder

Paralichthys olivaceus. Aquaculture, 220 (1-4): 725-735.

Gunasekera RM, Shim KF, Lam TJ (1995). Effect of dietary protein level on puberty, oocyte growth and egg chemical composition in the tilapia, Oreochromis niloticus (L.) Aquaculture, 134 (1-2): 169-183.

Gunasekera RM, Shim KF, Lam TJ (1996a). Effect of dietary protein level on spawning performance and amino acid composition of eggs of Nile tilapia, Oreochromis niloticus. Aquaculture, 146 (1-2): 121134.

Gunasekera RM, Shim KF, Lam TJ (1996b). Influence of protein content of broodstock diets on larval quality and performance in Nile tilapia, Oreochromis niloticus (L.). Aquaculture, 146 (3-4): 245-259.

Gunasekera RM, Shim KF, Lam TJ (1997). Influence of dietary protein content on the distribution of amino acids in oocytes, serum and muscle of Nile tilapia, Oreochromis niloticus (L.). Aquaculture, 152 (1-4): 205-221.

Harel M, Tandler A, Kissil GW, applebaum SW (1994). The kinetics of nutrient incorporation into body tissues of gilthead seabream (Sparus aurata) females and the subsequent effects on egg composition and egg quality. British Journal of Nutrition, 72: 45-58.

Hardy RW, Shearer KD, King IB (1984). Proximate and elemental composition ofdeveloping eggs and maternal soma of pen-reared coho salmon (Oncorhynchus kisutch) fed production and trace element fortified diets. Aquaculture, 43 (1-3): 147-165.

Hardy RW, Matsumoto T, Fairgrieve WT, Stickney RR (1990). The effects of dietary lipid source on muscle and egg fatty acid composition and reproductive performance of Coho Salmon (Oncorhynchus kisutch).
In: Takeda, M., Watanabe, T. (Eds.), The Current Status of Fish Nutrition in Aquaculture. Proc. Third Int. Symp. on Feeding and Nutr. in Fish, Japan Translation Centre, Tokyo, pp. 347-356

Hirshfield M.F (1980. An experimental analysis of reproductive effort and cost in the Japanese Medaka, Oryzias latipes. Ecology, 61: 282-292.

Izquierdo MS, Fernández-Palacios H, Tacon AGJ (2001). Effect of broodstock nutrition on reproductive performance of fish. Aquaculture, 197: 25-42.

Karlsen O, Holm JC, Kjesbu OS (1995). Effects of periodic starvation on reproductive investment in first time spawning Atlantic cod (Gadus morhua L.). Aquaculture, 133 (2):159-170.

Kestemont P, Cooremans J, Abi-ayaD A, Melard C (1999). Cathepsin L in eggs and larvae of perch Perca fluviatilis: variations with developmental stage and spawning period. FishPhysiology and Biochemistry, 21 (1): 59-64.

Kuznetzov VA, khalitov NK (1978). Alterations in the fecundity and egg quality of theroach, Rutilus rutilus, in connection with different feeding conditions. Journal of Ichthyology, 18: 63-70.

Kjesbu OS, Witthames PR, Solemdal P, Walker MG (1998). Temporal variations in the fecundity of ArctoNorwegian cod (Gadus morhua) in response to natural changes in food and temperature. Journal of Sea Research, 40 (3-4): 303-321.

Kjørsvik E, Mangor-Jensen A, Holmefjord L (1990). Egg quality in fishes. Advances in Marine Biology, 26: 71113.

Kjørsvik E, Hoehne-Reitan K, Reitan KI (2003). Egg and larval quality criteria as predictive measures for juvenile production in turbot (Scophthalmus maximus L.). Aquaculture,227 ( 4): 9-20.

Lavens $P$, Lebegue $E$, Jaunet $H$, Brunel $A$, Dhert $P$, Sorgeloos P (1999). Effect of dietary essential fatty acids and vitamins on egg quality in turbot broodstocks. Aquaculture Intemational, 7(4): 225-240.

Ma Y, Kjesbu OS, Jorgensen T (1998). Effects of ration on the maturation and fecundity in captive Atlantic herring (Clupea harengus). Can. J. Fish. Aquat. Sci., 55 (4): 900-908

ManisserY JK, Krishnamurthy D, Gangadhara B, Nandeesha MC (2001). Effect of varied levels of dietary protein on the breeding performance of common carp Cyprinus carpio.Asian Fisheries Science, 14 (3): 317-323.

Mazorra C, Bruce M, Bell JG, Davie A, Alorend E, Jordan $\mathrm{N}$, Rees J, Papanikos N, Portero M, Bromage N (2003). Dietary lipid enhancement of broodstock reproductive performance and egg and larval quality in Atlantic halibut (Hippoglossus hippoglossus). Aquaculture, 227 (1-4): 21-33. 
McKay I and Mann KH (1969). Fecundity of two cyprinid fishes in the River Thames, Reading,England. J. Fish Res. Bd. Can., 26: 2795-2805

Metailler R, Aldrin J P, Messager JL, Mevel G, Stephan G (1981). Feeding of european sea-bass Dicentrarchus labrax: role of protein level and energy source. J. World Maricul. Soc. 12 117-118.

Mourente G and Odriozola JM (1990). Effect of broodstock diets on lipid classes and their fatty acid composition in eggs of gilthead sea bream (Sparus aurata L.). Fish Physiol. Biochem., 8 (2):93-101.

Navas, J.M., M. Bruce, M. Trush, B.M. Farndale, N. Bromage, S. Zanuy, M. Carrillo, Bell JG, Ramos J (1997). The impact of seasonal alteration in the lipid

Composition of broodstock diets on egg quality in the European sea bass. J. Fish Biol., 51: 760-773.

Peres G (1981). In nutrition des poissons (op. cit.) Enzymologie digestive. I Les prothéases, l'amylase, les enzymes chitinolytiques, les laminarinases, 55-67.

Robb AP (1982). Histological observations on the reproductive biology of the haddock,

Melanogrammus aeglefinus (L.). Journal of Fish Biology, 20 (4): 397-408.

Rodriguez C, Cejas JR, Martin MV, Badia P, Samper M, Lorenzo A (1998). Influence of n-3 highly unsaturated fatty acid deficiency on the lipid composition of broodstockgilthead seabream (Sparus aurata L.) and on egg quality. Fish Physiology and Biochemistry, 18(2): 177-187.

Sandnes K, Ulgenes Y, Braekkan OR, Utne F (1984). The effect of ascorbic acid supplementation in broodstock feed on reproduction of rainbow trout (Salmo gairdneri).

Aquaculture, 43: 167-177.

Scott DP (1962). Effect of food quantity on fecundity of rainbow trout, Salmo gairdneri. J. Fish. Res.Board Can., 19: 715-731

Siddiqui AQ, Al-Hafedh YS, Ali SA (1998). Effect of dietary protein level on the reproductive performance of Nile tilapia, Oreochromis niloticus (L.). Aquaculture Research, 29(5): 349-358.

Torrans L and Lowell F (2001). Use of tilapia as supplemental forage for channel catfish broodstock. North American Journal of Aquaculture, 63 (3): 215221.

Trippel EA, Castell JD, Neil SRE, Blair TJ (2000). Assessment of egg quality of haddock (Melanogrammus aeglefinus) in paired matings. In Norberg, B.; Kjesbu, O.S.; Taranger GL, Andersson E, Stefansson SO(Ed.): Bergen, Norway. Proceedings of the $6^{\text {th }}$ International Symposium on the Reproductive Physiology of Fish, pp. 405-407.

Tandler A, Harel M, Koven WM, Kolkovski S (1995). Broodstock and larvae nutrition in gilthead seabream Sparus aurata new findings on its mode involvement in improving growth,survival and swimbladder inflation. Israeli Journal of Aquaculture/Bamidgeh, 47 (3-4): 95111.

Washburn BS, Frye DJ, Hung SSO, Doroshov SI, Cante FS (1990). Dietary effectson tissue composition, oogenesis and the reproductive performance of female rainbow trout (Oncorhynchus mykiss). Aquaculture, 90: 179-195.

Watanabe T, Arakawa T, Kitajima C, Fujita S (1984a). Effect of nutritínal quality of broodstock diet on reproduction of red seabream. Bulletin of the Japanese Society of Scientific Fisheries, 50 (3): 495501.

Watanabe T, Itoh A, Murakami A, Tsukashima Y, Kitajima C, Fujita S (1984b). Effect of nutritional composition of diets on chemical components of red seabream broodstocks and eggs produced. Bulletin of the Japanese Society of ScientificFisheries, 50 (3):503515.

Watanabe T, Itoh A, Murakami A, Tsukashima Y, Kitajima C, Fujita S (1984c). Effect of nutritíonal quality of diets given to broodstock on the verge of spawning on reproduction of red seabream. Bulletin of the Japanese Society of Scientific Fisheries, 50 (6):10231028.

Watanabe T, Takeuchi T, Saito M, Nishimura K (1984d). Effect of low protein-high calorie or essential fatty acid deficiency diet on reproduction of rainbow trout. Nippon Suisan Gakkaishi, 50 (7): 1207-1215.

Watanabe, T, Itoh A, Satoh S, Kitajima C, Fujita S (1985a). Effect of dietary protein levels and feeding period before spawning on chemical components of eggs produced by red sea bream broodstock. Bull. Jap. Soc. Sci. Fish., 51 (9): 1501-1509.

Watanabe T, koizumi T, Suzuki H, Satoh S, Takeuchi T, Yoshida N, Kitada T, Tsukashima Y (1985b). Improvement of quality of red sea bream eggs by feeding broodstock on a diet containing cuttlefish meal or on raw krill shortly before spawning. Bull. Jap.Soc. Sci. Fish., 51 (9): 1511-1521.

Watanabe T, Fujimura T, Lee MJ, Fukusho K, Satoh S, Takeuchi T (1991b). Nutritional studies in the seed production of fish. 21. Effect of polar and nonpolar lipids from krill on quality of eggs of red seabream Pagrus major. Bulletin of the Japanese Society of Scientific Fisheries, 57: 695-698.

Wee KL, Tuan NA (1988). Effects of dietary protein level on growth and reproduction in Nile tilapia (Oreochromis niloticus). ICLARM Conference Proceedings, 15: 623.

Wootton RJ (1979). Energy costs of egg production and environmental determinants of fecundity in telesot fishes. Symp. Zool. soc. Lond., 44: 133-159.

Yone Y, Fuji M (1975). Studies on nutrition of red sea bream. XI. Effect of w3 acid supplement in a corn oil diet on growth rate and feed efficiency. Nippon Suisan Gakkaishi, 41: 73-77. 